\title{
FINITE ELEMENT ANALYSIS OF CONVENTIONAL REINFORCED CONCRETE AND STEEL FIBRE REINFORCED CONCRETE IN SLAB- COLUMN JOINT
}

\author{
Sushant R Magdum ${ }^{1}$, Shilpa A. Veerabhadrannavar ${ }^{2}$ \\ ${ }^{1}$ MTech Student, Department of Civil Engineering, SVCE, Bangalore \\ ${ }^{2}$ Assistant Professor, Department of Civil Engineering, SVCE, Bangalore
}

\begin{abstract}
Flat slabs are widely used in construction due to its architectural flexibility, good aesthetic view, uncomplicated formwork and less construction time. But as we know that under the large axial loads, gravity loads and seismic loads the flat slab is poor in resisting the punching shear which causes slab-column joint failure and further results in the collapse of the structure, so there is a need to improve flat slab performance. In this particular study the Flat slab building G+12 is modeled, analyzed and designed as per IS 456:2000 by considering suitable load conditions under seismic zone IV as per IS 1893:2002 in E-Tabs software. An interior column strip slabcolumn joint is considered and designed in ETabs and SAFE for the column and slab respectively. Analytical modeling of column strip slab of 2500x2500mm and column dimension of 500x600mm having a height of $1500 \mathrm{~mm}$ is done in ANSYS. The boundary condition of the slab is simply supported at all sides and the column is pinned at both upper and lower face. The conventional reinforced slab and Steel Fibre reinforced Self-Compacting concrete slab properties are taken and fed into the ANSYS workbench and Linear static analysis to carry out the column strip slab-column joint behavior against axial loads, reaction force, gravity loads and lateral loads. The Total Deformation, Equivalent Von-mises stresses and Equivalent Elastic strain in slab and the slab-column joint are studied and compared. For SFRSCC slab used in slab-column joint shows almost 15\% less Total Deformation of the structure compared to Conventional RC slab against the Axial and gravity loads, whereas during the lateral loads it almost twice effective as compared to conventional RC slab. Similarly the stresses and strains are reduced to large extent in SFRSCC slab which make it better material when used in joint which increases its performance.
\end{abstract}

Keywords: ETABs 2015, Axial Loads, Lateral Loads, Reaction force, SAFE, Column strip slab-column joint, SFRSCC, Linear Static Analysis, ANSYS workbench 16.

\section{INTRODUCTION}

\subsection{Flat Slab}

Flat slabs are being widely used in construction because of its vast advantages like architectural adaptability, much clear space, reduced building height, easier formwork, less construction time and economical compared to regular practice of construction. Mostly the flat slabs are studied under gravity loads, axial loads only but for the lateral loads the failure arises in the slab-column joint due to unbalanced moments and shear forces causing the joint to crack and resulting in collapse of structure due to its brittle nature. So we must design and incorporate special method using SFRC (Steel Fibre Reinforced Concrete) in slab to increase the ductility in the slab-column connection.

(a) Flat slab without Column Head and Drop Panel: This is the most usual practice of supporting a slab on the column directly and also called a flat plate or typical flat slab. $* * *$

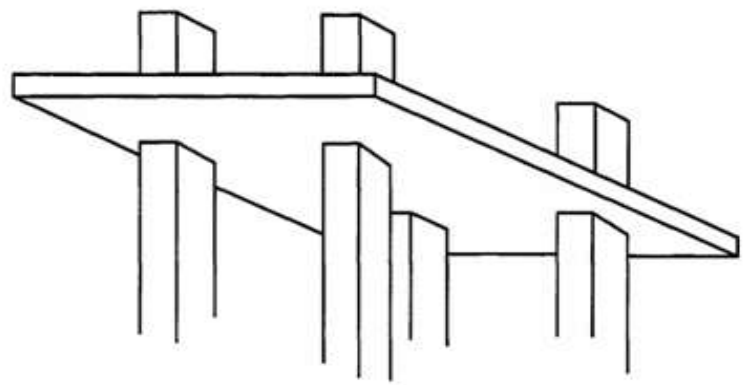

Fig 1.1 Flat Plates

\subsection{Punching Shear}

Punching shear additionally called the two ways shear failure of RC flat plates subjected to high concentrated forces acting at surface. It occurs at slab-column support joint due to punching effect and shows very less warnings before failure. In the typical flat plate punching failure is characterized by the crack formation around the portion of the periphery of column. This failure is very critical when determining the depth of flat plates. Studying the behavior of the joint is important for engineers to design a safe and sustainable structure. 
In the flat plates it arises from the formation of diagonal tension cracks around the loaded area, which results in a conical failure pattern shown in Fig 1.3

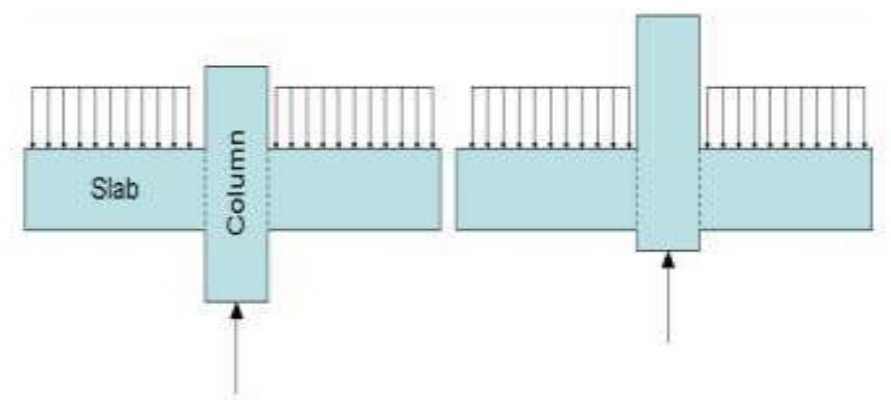

Fig 1.2 Flat Slabs with Reaction Forces

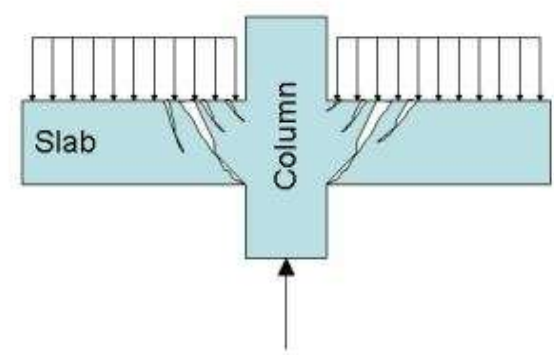

Fig 1.3: Failure due to Punching Shear

Punching shear occurs in flat plates by showing a cone shaped cracking starting from the upper surface of the slab. Although it's generally initiated by flexural failure, and is a brittle failure mode and the risk of progressive collapse requires a higher care in structural design.

\subsection{Steel Fibre Reinforced Concrete}

Lately, SFRC has enhanced from a new material to one which has now gained popularity in numerous civil engineering fields. It has become more common to use SFRC due to its numerous applications. The steel fibres when intermixed with concrete the structural strength of concrete increases. So the common applications of SRFC are in tunnel linings, slabs and airport pavements.

Indefinite types steel fibres are used as concrete reinforcement but round fibres are much common type with the diameter ranging from 0.25 to $0.75 \mathrm{~mm}$. The main advantage of disfigured or deformed fibres is their ability to dispense uniformly within the concrete matrix.

The length, diameter, volume and the aspect ratio of steel fibres are beneficial components in SFRC. The advantages of SFRC are that increases the tensile strength, durability of concrete and deformational capacity. It's high resistance to impact loads, freezing and thawing. It's is also called crack arrestor \& distributes high localized stresses.

The main disadvantages of SFRC are that it's uneconomical and have high repair and maintenance cost.

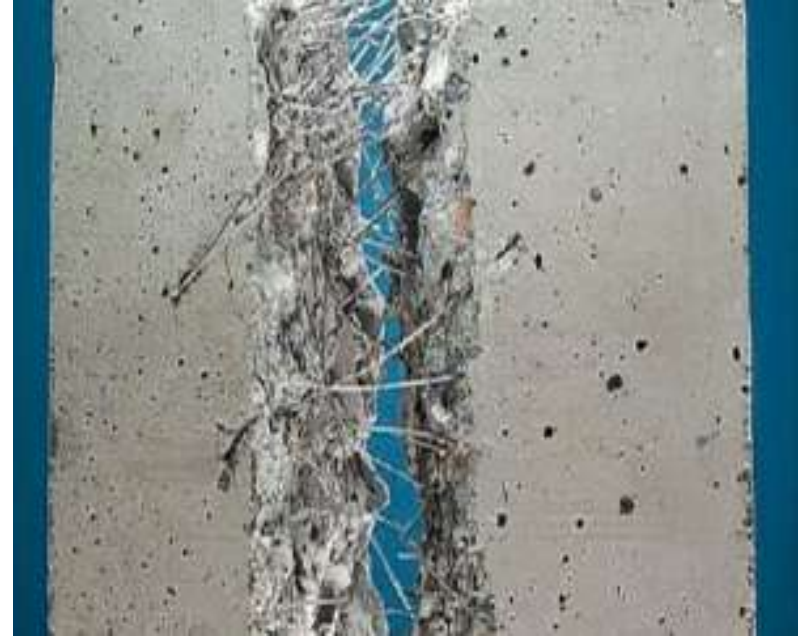

Fig 1.4: Concrete Reinforced with Steel Fibres

\subsection{Self Compacting Concrete}

The Self-Compacting Concrete is the concrete used in the complex structures where there are more reinforcements where usually vibrators cannot be used. The SCC doesn't require the vibration and it is easily placed in any complex reinforced structures by self-compacting or self-leveling property. The super plasticizer, chemical or mineral admixtures used in conventional concrete which increases the flow-ability, workability and hence concrete placing becomes easier. The pros of SCC are having lesser construction time, easier placing of concrete, no vibration needed, reduces the man power, excellent surface finish and increased durability. The major disadvantage is that it's costly than the conventional concrete.

\subsection{Need for the Study}

- A slab column joint is structurally less efficient when subjected to high concentrated and lateral loads such as axial, earthquake, wind or any impact load. A high ductility is needed around the joint to meet the required performance under such cyclic loadings. So there is a need for this study.

- $\quad$ Efforts are made to develop a more efficient flat plate building with better resistance to punching shear failure against lateral, axial and gravity loads. Since the Steel Fibre Reinforced Concrete has capacity to perform well due to its more ductile behavior, so only the slab is incorporated with SFRSCC and analyzed its performance in joints.

\subsection{Objective of the Study}

- To study the Behavior of one Slab-Column joint under Axial loads and Lateral loads using conventional reinforced concrete and SFRSCC. The flat plate building modeled, analyzed and designed against axial and lateral loads in E-Tabs software.

- Comparison of Deformations in conventional slab-column joint and steel fiber reinforced slab-column joint.

- The Comparison of Equivalent von-mises Stresses and Equivalent Elastic Strains in Conventional Concrete slabcolumn joint and Steel Fiber Reinforced Concrete slabcolumn joint and studying the Punching shear failure. 


\subsection{Scope of the Study}

- The present study distinguishes between the conventional and Steel Fiber Reinforced Concrete behavior at slab column joint.

- $\quad$ This study analyses the deformations of joint structure and in slab, punching shear failure, stresses and strains in slab measured from the center of column.

\section{MODEL ANALYSES}

\subsection{Analytical Programme}

The $\mathrm{G}+12$ office flat plate building is modeled by taking column dimensions $500 \mathrm{~mm}$ X $600 \mathrm{~mm}$ and slab thickness as 200mm according to IS 456:2000 in ETABs. The Live load of $4 \mathrm{kN} / \mathrm{m}^{2}$ \& Floor finish $1 \mathrm{kN} / \mathrm{m}^{2}$ is applied on slabs and as usual the dead load is default assigned to the columns and slabs. The earthquake loads and response spectrum analysis is done as per IS 1893:2002 under seismic zone IV and Type I rocky soil is considered for the study.

The model is analyzed and the members passed or failed are verified. If passed then the axial forces, moments, shear forces for the typical load combination is noted down. The column design is referred for further study and it closely matches the manual design carried out for the one particular column with same typical axial load and unbalanced moment.

The $8^{\text {th }}$ floor flat slab with same loadings and properties is exported from ETABS to SAFE software to carry out the design. The Direct Design Method is usually carried out manually and compared with software design. The close results have obtained for both middle and column strip.

The particular $8^{\text {th }}$ floor slab of dimension $2500 \mathrm{mmX} 2500 \mathrm{~mm}$ (1250mm from the centre of column in both directions) which is a Column Strip (B-2 joint elevation from ETABS) and Column of height $1500 \mathrm{~mm}(750 \mathrm{~mm}$ from the centre of slab in above and below direction) is taken for further study by applying the laws of similitude.

This Slab \& Column Joint is modeled in ANSYS software against the axial loads on column top face, base reaction at bottom of column face and lateral load at the edge of the column in X-Direction. The slab is simply supported in all directions and column has hinged supports at the Top and Bottom face. The same model but with added Steel Fibre Reinforced Self-Compacting Concrete Slab (SFRSCC) properties are fed in ANSYS material properties of concrete and then Linear Static analysis is carried out and comparison of Conventional Reinforced Concrete Slab-Column joint and Steel Fibre Reinforced Concrete Slab-Column joint is made and results are discussed.

[Note: The SFRSCC properties are only for the slab and not for the column]

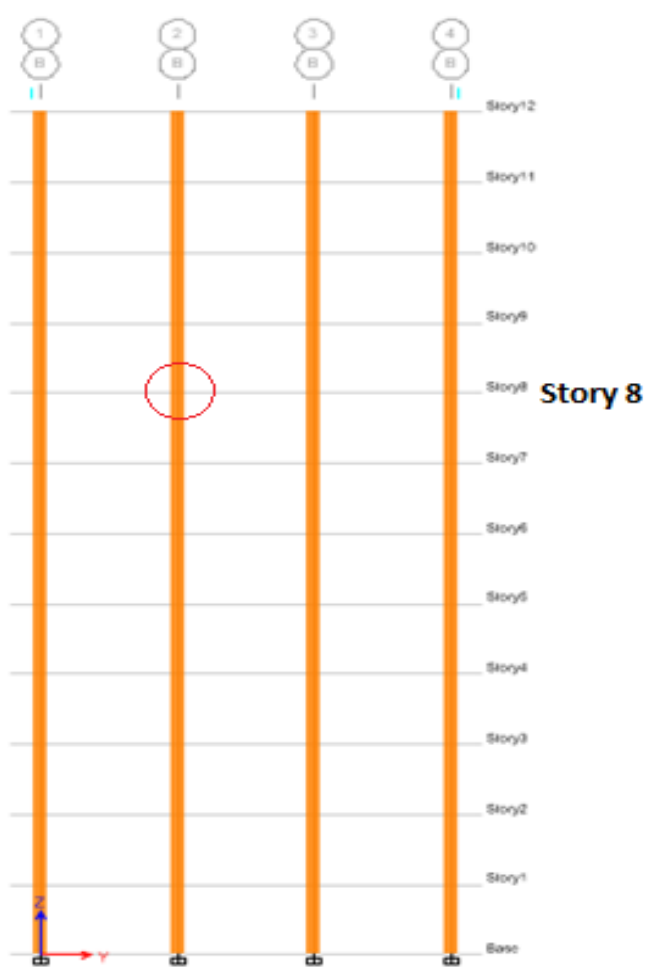

Fig: 2.1 Elevation view of $\mathrm{G}+12$ building

\section{DESIGN FORCES}

\subsection{Axial Loads}

The Axial load for the typical load case was found to be 1530 $\mathrm{kN}$ from ETAbs.

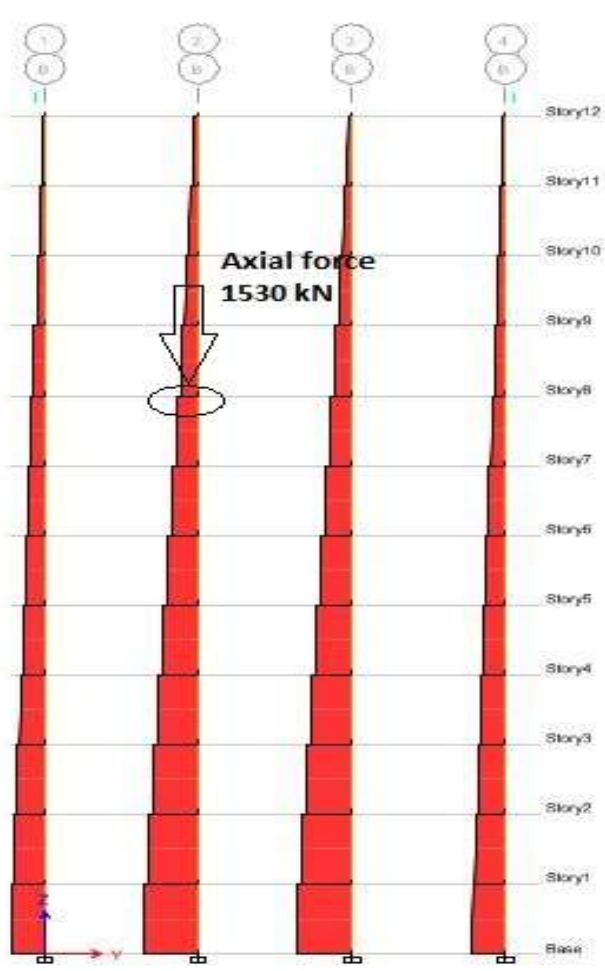

Fig 3.1; Axial Load Value ETABs 


\subsection{Lateral Loads}

he lateral load at story $8^{\text {th }}$ was approx. $70 \mathrm{kN}$ but as we have applied at the tip of the column edge which is $750 \mathrm{~mm}$ above the slab we have taken $80 \mathrm{kN}$ load in EQ-X in ETABs.

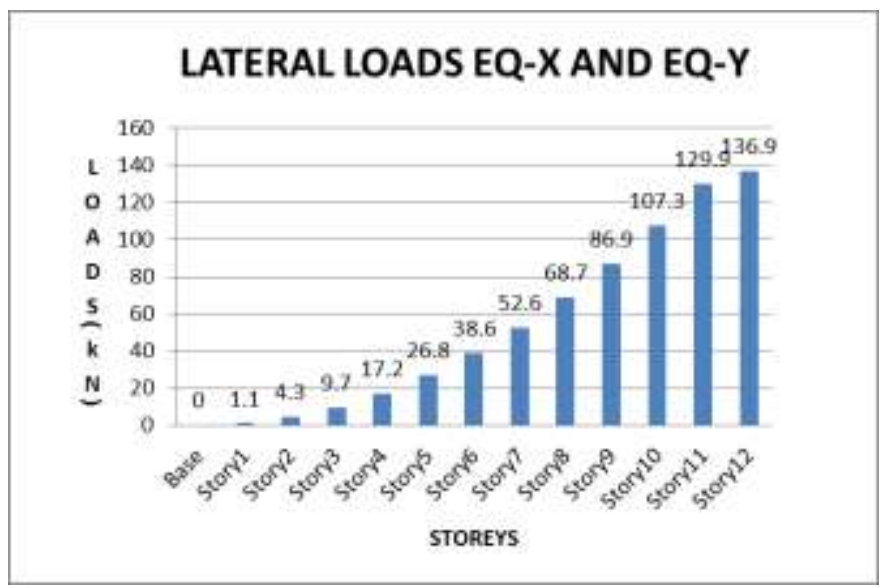

Fig 3.2: Lateral loads EQX and EQY

\subsection{Reaction Load}

The reaction force applied at the column lower support is 1845 $\mathrm{kN}$ got from SAFE software.

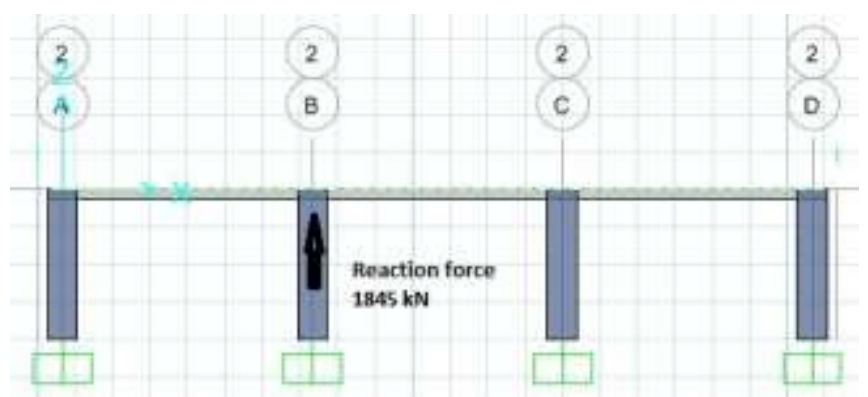

Fig 3.3: $8^{\text {th }}$ story slab with Reaction force at column joint

\section{REINFORCEMENT DESIGN}

COLUMN: From ETabs we get Column design. Column is been provided with 12 no's of longitudinal bars of $25 \mathrm{~mm}$ diameter.

The lateral ties are provided with $8 \mathrm{~mm}$ diameter bars at $125 \mathrm{~mm} \mathrm{C} / \mathrm{C}$.

SLAB: From SAFE we get slab flat slab design of column and middle strip.

\section{Column Strip:}

Top Bars: 12mm diameter bars @ 125mm C/C

Bottom bars: 10mm diameter bars @ 125mm C/C

\section{Middle Strip:}

Top bars: 8mm diameter bars @ $275 \mathrm{~mm} \mathrm{C/C}$

Bottom bars: 8mm diameter bars @ 200mm C/C
These ETABS column design and SAFE slab design closely matches with manual design done separately. But we have only considered column strip as the analysis can take consume much time in ANSYS workbench 16.0.

\section{FINITE ELEMENT ANALYSIS}

1. In ANSYS workbench 16.0 software the material properties of Conventional reinforced concrete and the Steel Fibre reinforced self-compacting concrete are set according to the paper referred in the Engineering Data. The following properties are fed up initially before carrying out the Linear static analysis in Static Structural.

Table 1: Material Properties

\begin{tabular}{|l|l|}
\hline PROPERTIES & DETAILS \\
\hline $\begin{array}{l}\text { Grade of Conventional } \\
\text { Reinforced Concrete }\end{array}$ & $\mathrm{M} 30$ \\
\hline Density & $2300 \mathrm{Kg} / \mathrm{m}^{3}$ \\
\hline Poisson's ratio & 0.2 \\
\hline Young's modulus & $27386 \mathrm{MPa}$ \\
\hline $\begin{array}{l}\text { Compressive yield } \\
\text { strength }\end{array}$ & $30 \mathrm{MPa}$ \\
\hline Grade of SFRSCC & $\mathrm{M} 55$ \\
\hline Density & $2404 \mathrm{Kg} / \mathrm{m}^{3}$ \\
\hline Poisson's ratio & 0.2 \\
\hline Young's modulus & $37080 \mathrm{MPa}$ \\
\hline Grade of Steel & Fe 415 \\
\hline Density & $7810 \mathrm{Kg} / \mathrm{m}^{3}$ \\
\hline Tensile yield strength & $415 \mathrm{MPa}$ \\
\hline
\end{tabular}

2. The column strip slab having depth $200 \mathrm{~mm}$ and Dimensions $2500 \times 2500 \mathrm{~mm}$ and the column of 500x600mm at the centre of slab with all reinforcements are modeled in Geometry.

3. The Model of slab-column joint with only Axial load acting on upper part column, slab load and the Reaction load from bottom support containing Conventional Reinforced Slab and Steel Fibre Reinforced Slab is modeled.

4. The manual connections in software between all the materials like column longitudinal reinforcements, column stirrups, slab concrete, Column concrete, slab reinforcement etc. is done. The automatic meshing is assigned.

5. The boundary conditions are simply supported slab at all sides and pinned support column at both upper and lower face. The forces and loads are applied and the Model is analyzed by applying time varying loads with 5 steps of 1 second each. Results are extracted.

6. Two models of CRC slab and SFRSCC slab-column joint with A.L, Reaction force and Slab gravity Load are compared (model 1\&2) and Same models with A.L, Reaction Force, Slab gravity load and Lateral load are compared (Model $3 \& 4$ ). The two tables are given below with 5 load steps: 
Table 2: Loads for Model 1 and 2

\begin{tabular}{|l|l|l|l|}
\hline $\begin{array}{l}\text { Time } \\
(\mathbf{s})\end{array}$ & $\begin{array}{l}\text { Axial force } \\
(\mathbf{N})\end{array}$ & $\begin{array}{l}\text { Reaction } \\
\text { Force } \\
(\mathbf{N})\end{array}$ & $\begin{array}{l}\text { Slab } \\
\text { Pressure } \\
(\mathbf{M P a})\end{array}$ \\
\hline 0 & 0 & 0 & 0 \\
\hline 1 & $3.06 \mathrm{e} 10^{3}$ & $369 \mathrm{e} 10^{3}$ & $1 \mathrm{e} 10^{-3}$ \\
\hline 2 & $612 \mathrm{e} 10^{3}$ & $738 \mathrm{e} 10^{3}$ & $2 \mathrm{e} 10^{-3}$ \\
\hline 3 & $918 \mathrm{e} 10^{3}$ & $1107 \mathrm{e} 10^{3}$ & $3 \mathrm{e} 10^{-3}$ \\
\hline 4 & $1224 \mathrm{e} 10^{3}$ & $1476 \mathrm{e} 10^{3}$ & $4 \mathrm{e} 10^{-3}$ \\
\hline 5 & $1530 \mathrm{e} 10^{3}$ & $1845 \mathrm{e} 10^{3}$ & $5 \mathrm{e} 10^{-3}$ \\
\hline
\end{tabular}

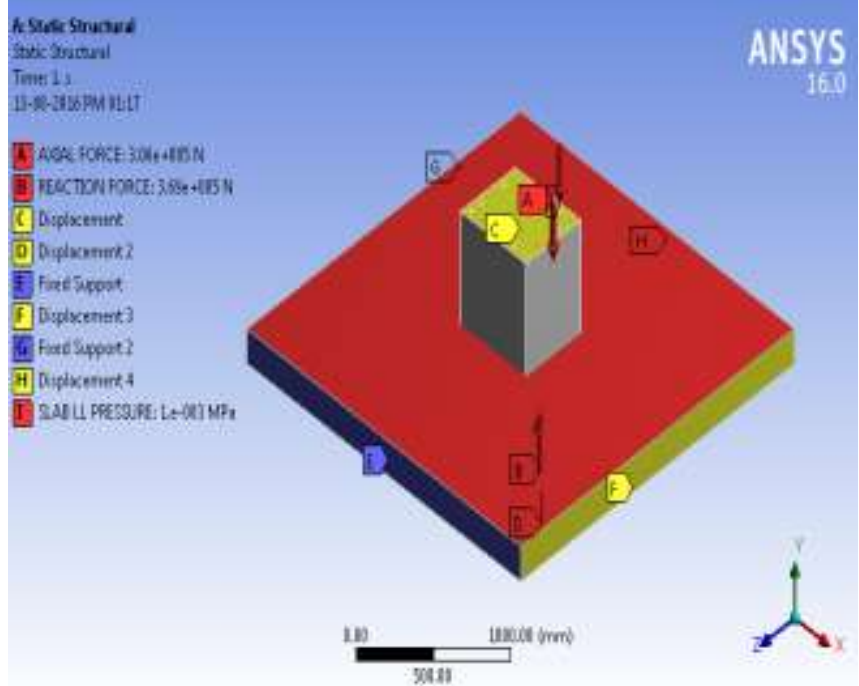

Model 1 and 2 ( Without Lateral Load )

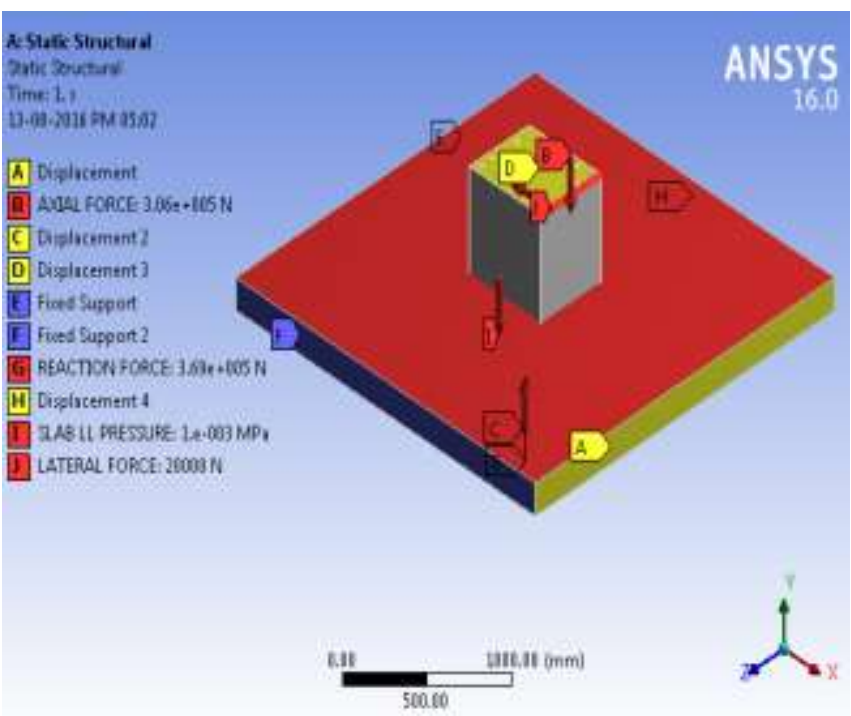

Model 3 and 4 ( With Lateral Load)

\section{COMPARISON}

1. Conventional and Steel Fibre Reinforced Self Compacting Concrete Slab Column-Joint with Axial Loading (10 steps)

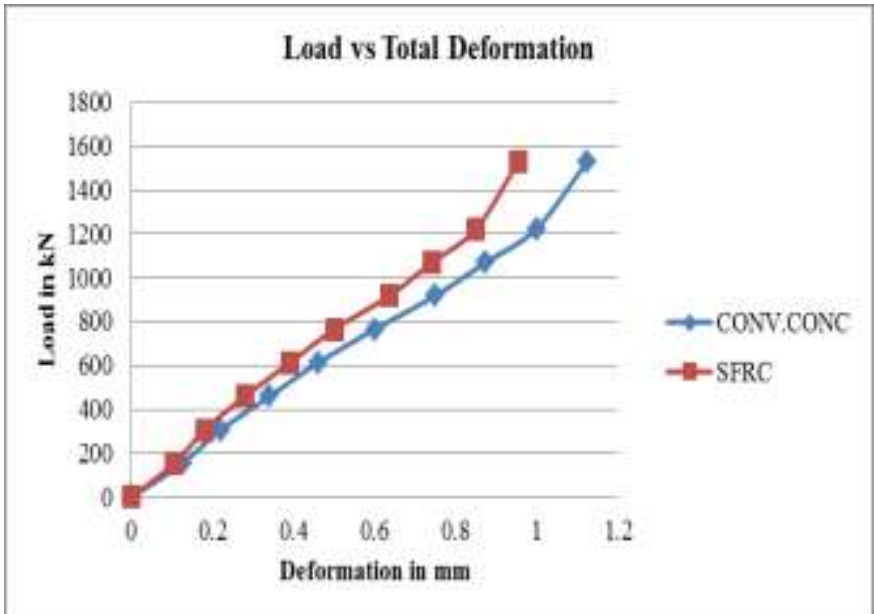

Graph 6.1: Load Vs Total Deformation of CRC and SFRSCC Slab-Column Joint

Fig 5.2: 3-D view of slab column joint Auto meshing 


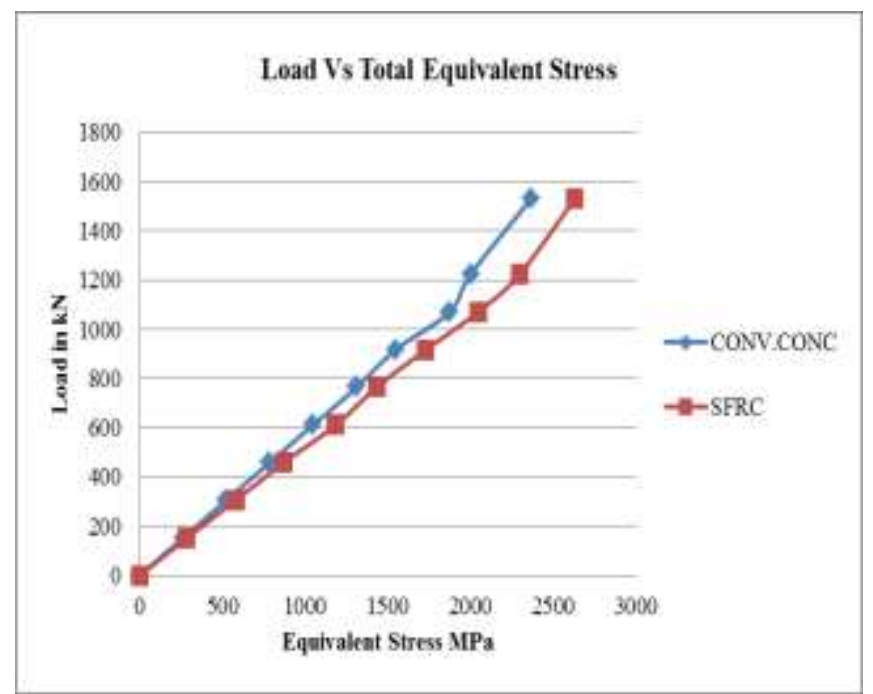

Graph 6.2: Load Vs Total Equivalent Stress in CRC and SFRSCC Slab-Column Joint

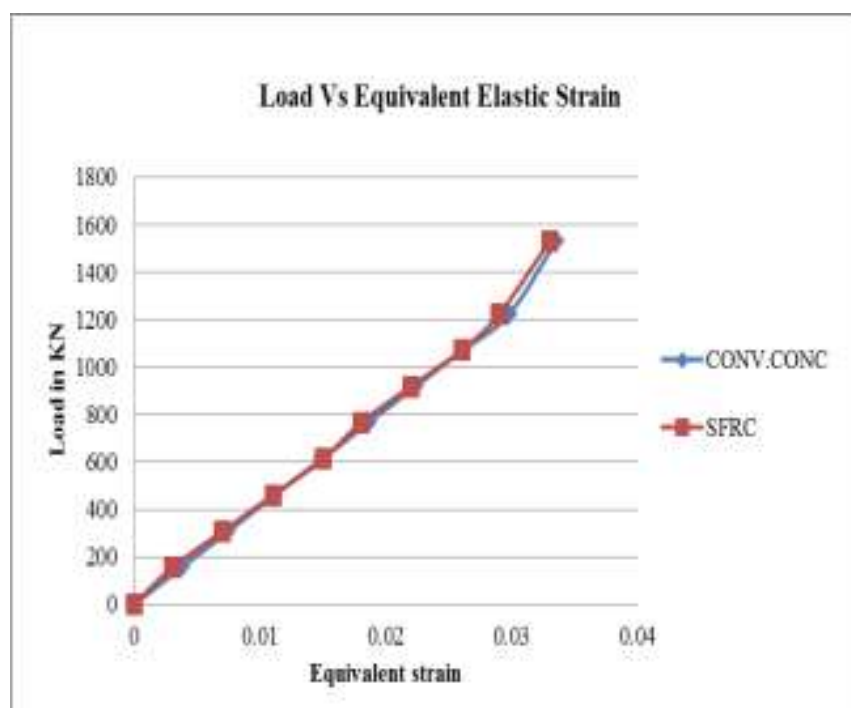

Graph 6.3: Load Vs Equivalent Elastic Strain for CRC and SFRSCC Slab-Column Joint

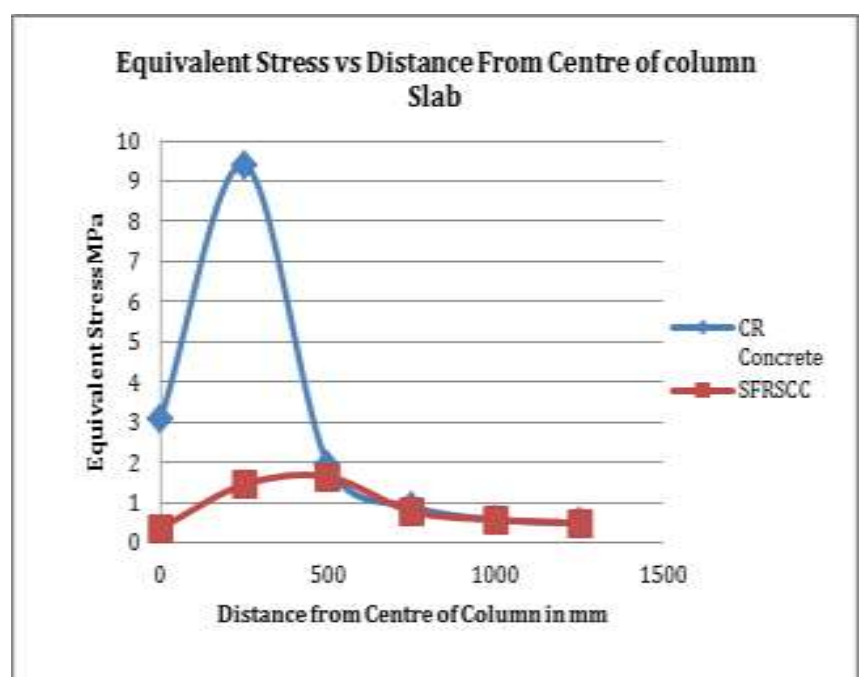

Graph 6.4: Equivalent stress vs Distance from the centre of column in slab

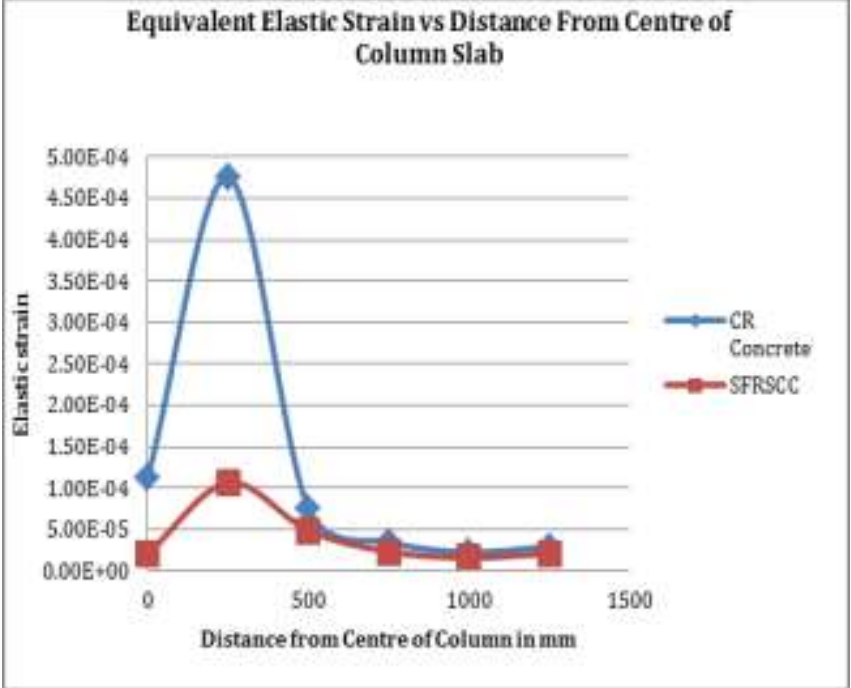

Graph 6.5: Equivalent Elastic Strain vs Distance from the centre of column in slab

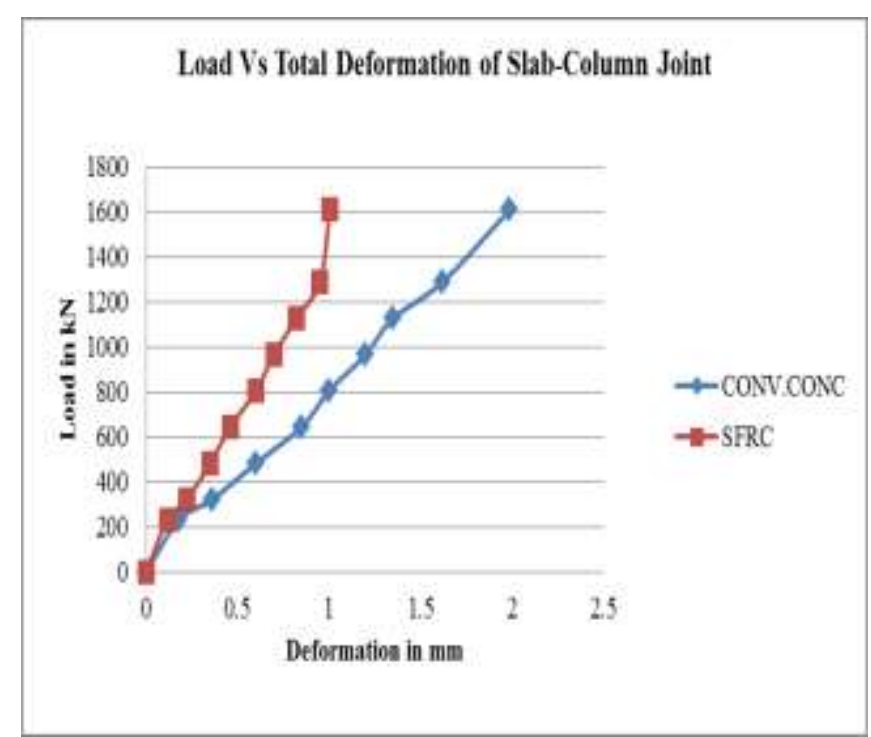

Graph 6.6: Load Vs Total Deformation of CRC and SFRSCC Slab-Column Joint

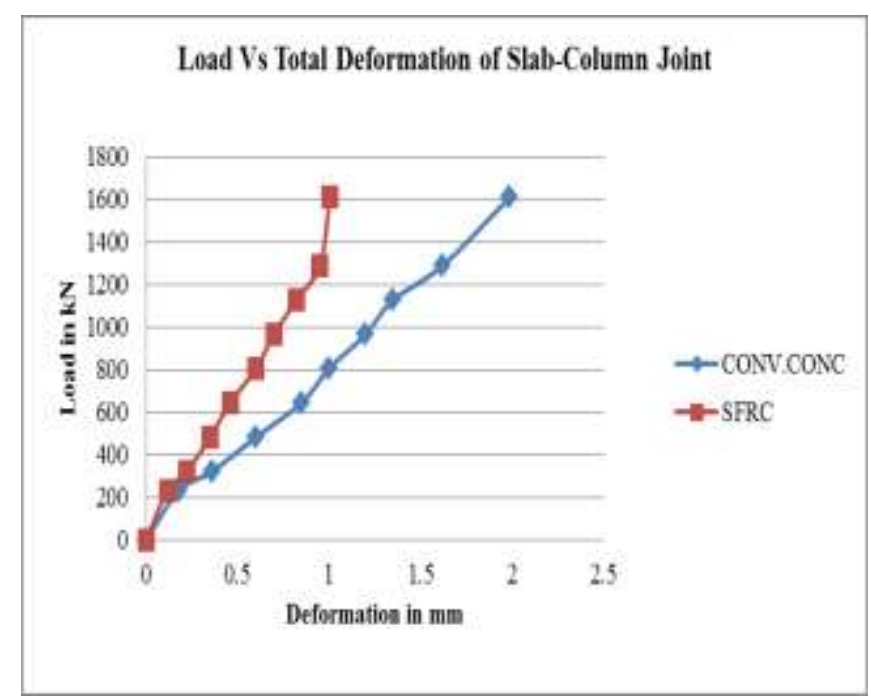

Graph 6.7: Load Vs Total Deformation of CRC and SFRSCC Slab-Column Joint with A.L and L.L 


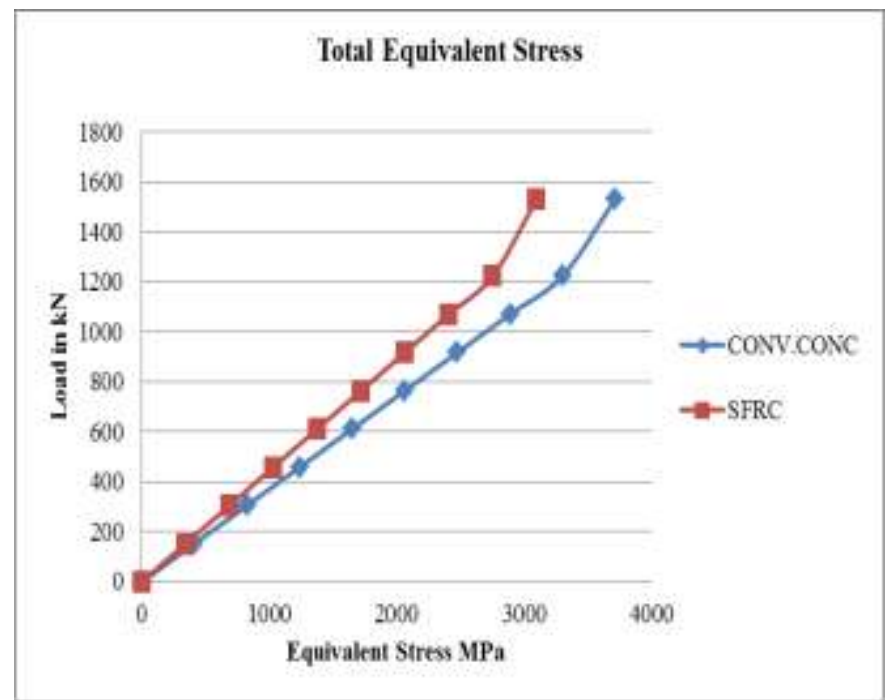

Graph 6.8: Load Vs Equivalent Stress in CRC and SFRSCC Slab-Column Joint

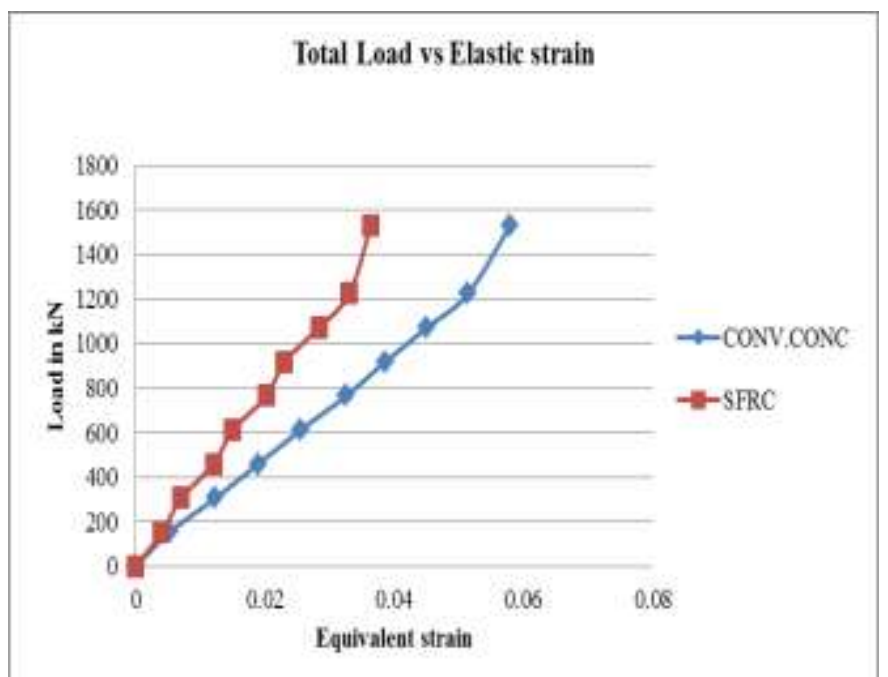

Graph 6.9: Load Vs Equivalent Elastic Strain in CRC and SFRSCC Slab-Column Joint

Equivalent Stress vs Distance From Centre of column Slab

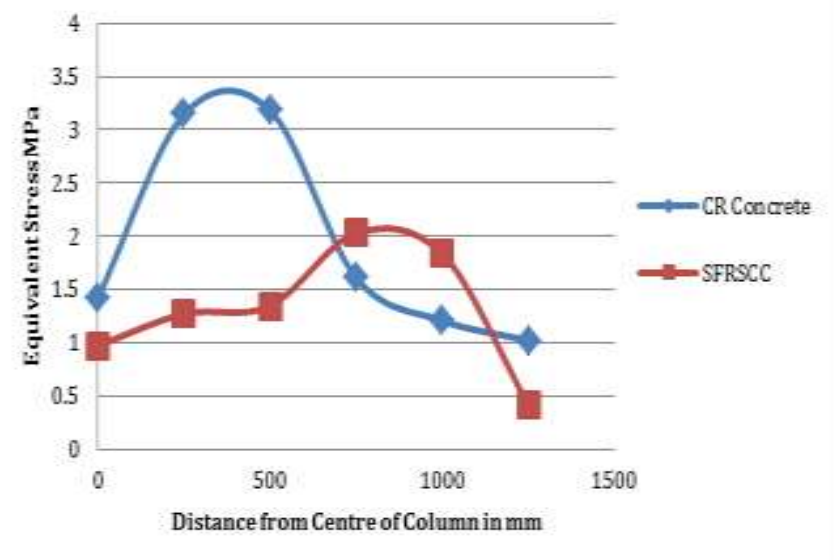

Graph 6.10: Equivalent stress vs Distance from the centre of column in slab

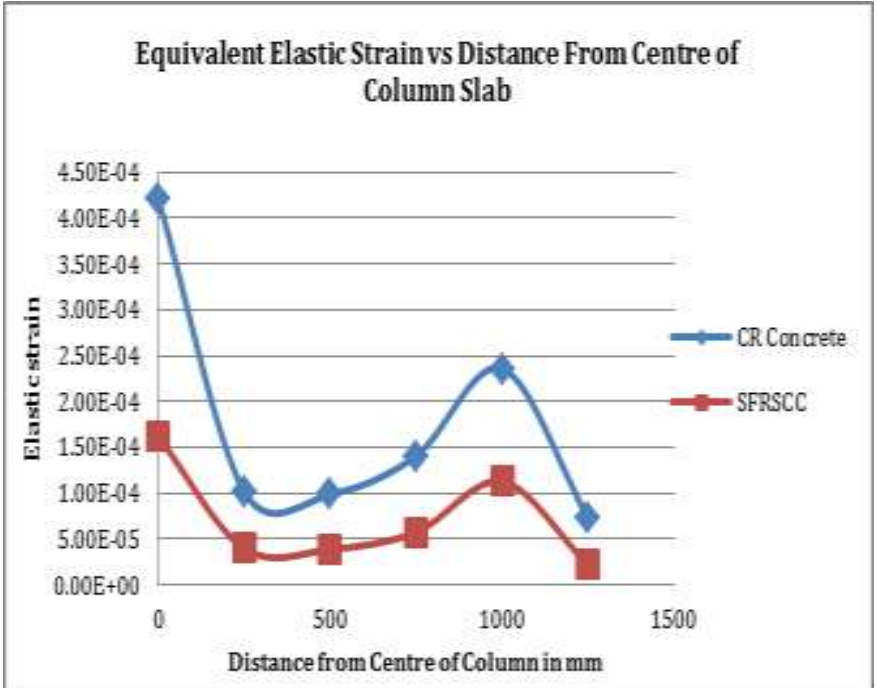

Graph 6.11: Equivalent Elastic Strain vs Distance from the centre of column in slab

\section{CONCLUSION}

1. The Slab-Column joint with the axial load on the column upper face and the Reaction force at the bottom face results in punching shear deformation of the joint and showing $15 \%$ less deformation for SFRSCC in slab-column joint compared to Conventional R.C slab-column joint.

2. During the Axial load, gravity load the Deformation is $24 \%$ less for SFRSCC slab when compared with Conventional RC slab and also we can conclude that Stresses and strains in SFRSCC slab are almost half of the stresses and strains in Conventional RC slab.

3. During Lateral loading along with axial load and gravity load acting on the structure we can see that the SFRSCC slabColumn joint tends to Deform 50\% less compared to Conventional RC slab-column joint.

4. During the Lateral loading the high stresses occurs at the joint. Stresses are high near the joint and less at the ends of slab. SFRSCC slab shows on average $60 \%$ less stresses than the CRC slab at the $250 \mathrm{~mm}$ distance from the centre of the column whereas $55 \%$ less stresses at the $1250 \mathrm{~mm}$ distance from the centre of column which is end of the slab.

5. Similarly for strains which are high at the joint and less at the ends of slab SFRSCC slab shows $65 \%$ less strains than the CRC slab.

6. Finally we can say that the Flat-plate building subjected to Axial, Gravity and Lateral load should be incorporated with the use of Steel Fibre Reinforced Self Compacting Concrete in slab only can give excellent results in terms of Total Deformation, Punching shear Deformation, Stresses and strains at the joints when compared to Conventional Reinforced Concrete used in Slab because of the Steel fibres have high tensile strength, High Stiffness and Ductility and also a crack arrestor which performs better in Joints. 


\section{REFERENCES}

\section{Papers Referred}

[1] Osman M. Ramadan, Kamal G. Metwally and Gehad S. Younis - "Punching Shear Analysis of Reinforced Concrete Flat Plates" (2015)

[2] Kavitha S, Umadevi R, Sugandha - "Seismic Vulnerability of Flat Plate Column Joint without Slab Shear Reinforcement" (2015)

[3] M. Priya, S. Greeshma and K. N. Suganya - "Finite Element Analysis of Slab - Column Joint under Lateral Loading" (2014)

[4] Alkarani, Ravindra. R - "Evaluation of punching shear in flat slabs" (2013)

[5] Viswanathan T.S, Mohan Ganesh G, Santhi A.S - "Shear stress distribution of flat-plate using Finite Element Analysis" (2012)

[6] Jin-kyu Song, Jubum Kim, Ho-Bum Song and JeongWon Song - "Effective punching shear and moment capacity of flat-plate column connection with shear reinforcements for lateral loading" (2012)

[7] Roberto Guidotti, Miguel Fernandez Ruiz and Aurelio Muttoni - "Behavior and design of slab-column joints" (2011)

[8] S.R. Hoseini Vaez, A.Kheyroddin and H. Naderpur - "3D Finite Element Simulation of Slab-column connections Strengthened with CFRP” (2008)

[9] Khaled S. Ragab - "Study Punching Shear of Steel Fibre Reinforced Self Compacting Concrete Slabs by Nonlinear Analysis" (2013)

[10] Maya Duque L, Fernandez Ruiz M, Muttoni A, Foster S.J - "Punching shear strength of steel fibre reinforced concrete slabs" (2012)

[11] Nuno Gouveia, Nelson Fernandes, Duarte Faria, Antonio Ramos and Valter Lucio - "Punching of Steel Fibre Reinforced Concrete Flat Slabs"

[12] Mohana H.S, Kavan M.R - "Comparative Study of Flat Slab and Conventional Slab Structure Using ETABS for Different Earthquake Zones of India" (2015)

[13] Sanjay P.N, Mahesh Prabhu K, Umesh S.S - "Behavior of Flat Slab RCC structure under Earthquake Loading" (2014)

[14] Navyashree K, Sahana T.S - "Use of flat slabs in Multistory Commercial building situated in high seismic zone" (2014)

\section{Text Books Referred}

[15] S.S. Bhavikatti - "Advance R.C.C. Design"

[16] M.S Shetty - "Concrete technology"

[17] S. Unnikrishna Pillai and Devdas Menon - Reinforced Concrete Design “

\section{Code Books Referred}

[18] IS 875 Part 1- Code of practice for design loads (other than earthquake) for buildings and structures part I-Dead loads - unit weights of building materials and stored materials.
[19] IS 875 Part 2- Code of practice for design loads (other than earthquake) for buildings and structures part 2Imposed loads.

[20] IS 875 Part3- Code of practice for design loads (other than earthquake) for buildings and structures part 3 wind loads.

[21] IS 1893:2002 - Criteria for Earthquake Resistant Design of Structures: Part 1 General provisions And Buildings 